\title{
Exergy and Exergoeconomic analysis of a Compressed Air Energy Storage combined with a District Energy System
}

\author{
Audrius Bagdanavicius, Nick Jenkins \\ Institute of Energy, Cardiff School of Engineering, Cardiff University, Cardiff, Wales, UK \\ bagdanaviciusa@cardiff.ac.uk,jenkinsn6@cardiff.ac.uk
}

\begin{abstract}
:
The potential for using heat generated during the compression stage of a Compressed Air Energy Storage system was investigated using exergy and exergoeconomic analysis. Two Compressed Air Energy Storage systems were analysed: Compressed Air Energy Storage (CAES) and Compressed Air Energy Storage combined with Thermal Storage (CAES-TS) connected to a district heating network. The maximum output of the CAES was $100 \mathrm{MWe}$ and the output of the CAES-TS was $100 \mathrm{MWe}$ and $105 \mathrm{MWth}$. The study shows that 308 GWh/year of electricity and $466 \mathrm{GWh} /$ year of fuel are used to generate $375 \mathrm{GWh} /$ year of electricity. During the compression of air $289 \mathrm{GWh} /$ year of heat is generated, which is wasted in the CAES and used for district heating in the CAES-TS system. Energy efficiency of the CAES system was around $48 \%$ and the efficiency of CAES-TS was $86 \%$.

Exergoeconomic analysis shows that the exergy cost of electricity generated in the CAES was $13.89 \mathrm{c} / \mathrm{kWh}$, and the exergy cost of electricity generated in the CAES-TS was 11.20 \$/kWh. The exergy cost of heat was $22.24 \mathrm{\$} / \mathrm{kWh}$ in the CAES-TS system. The study shows that CAES-TS has the potential to be used both as energy storage and heat source and could be a useful tool for balancing overall energy demand and supply.
\end{abstract}

\section{Keywords:}

Compressed Air Energy Storage, Thermal Energy Storage, Exergy Analysis, Exergoeconomic Analysis 


\section{Nomenclature}

$A_{i}$ - area of the external wall surface of thermal storage tank $\left(\mathrm{m}^{2}\right)$

$A_{q}$ - cross section area of stratified layer in thermal storage tank $\left(\mathrm{m}^{2}\right)$

$c_{p}$ - heat capacity $\left(\mathrm{J} \mathrm{kg}^{-1} \mathrm{~K}^{-1}\right)$

$c$ - average cost per unit of exergy $\left(\phi \mathrm{J}^{-1}\right)$

$\dot{C}-$ cost rate $\left(\varnothing \mathrm{s}^{-1}\right)$

$e-$ specific exergy $\left(\mathrm{kJ} \mathrm{kg}^{-1}\right)$

$E-\operatorname{exergy}(\mathrm{J})$

$\dot{E}$ - exergy flow rate $\left(\mathrm{J} \mathrm{s}^{-1}\right)$

$F$ - fuel energy (J)

$h_{\text {eff }}$ - effective heat transfer coefficient $\left(\mathrm{W} \mathrm{m}^{-3} \mathrm{~K}^{-1}\right)$

$H H V$ - higher heating value $\left(\mathrm{kJ} \mathrm{kg}^{-1}\right)$

$\dot{m}$ - mass flow rate $\left(\mathrm{kg} \mathrm{s}^{-1}\right)$

$P$ - pressure $(\mathrm{Pa})$

$t$ - time (s)

$T$ - temperature $(\mathrm{K})$

$U$ - heat loss coefficient $\left(\mathrm{W} \mathrm{m} \mathrm{m}^{-2} \mathrm{~K}^{-1}\right)$

$Q$ - heat energy (J)

$\dot{Q}$ - heat transfer rate $\left(\mathrm{J} \mathrm{s}^{-1}\right)$

$V$ - volume $\left(\mathrm{m}^{3}\right)$

$W-\operatorname{work}(\mathrm{J})$

$\dot{W}-\operatorname{power}\left(\mathrm{J} \mathrm{s}^{-1}\right)$

$z$ - height of stratified layer (m)

$\dot{Z}$ - capital cost rate $\left(\varnothing \mathrm{s}^{-1}\right)$

$\lambda_{\text {eff }}$ - effective heat conductivity ( $\mathrm{W} \mathrm{m}^{-1} \mathrm{~K}^{-1}$ )

$\rho-$ density $\left(\mathrm{kg} \mathrm{m}^{-3}\right)$

$\delta$ - coefficient, 0 or 1

\section{Subscripts and Superscripts}

$a-$ ambient

air - air

$c$-compressor

ch - charging 
$d h$ - district heating

dis - discharging

$e$-electrical

$f-$ fuel

$i$ - node number

in - inlet

$k$ - component number

out - outlet

$q$ - exergy or cost stream associated with thermal energy

ret-return

$s-$ stratified layer of thermal storage

th - thermal

tur - turbine

$w$ - exergy or cost stream associated with work

wall - cavern wall

\section{Introduction}

The capacity of electricity generation from renewable energy sources has been steadily increasing over the last decade. In Europe, although the share of hydropower in the renewable electricity generation mix remains the highest, wind power and solar PV have been the fastest growing renewable energy technologies in 2012. Wind power accounted for $38 \%$ and solar PV for $54 \%$ of all new renewable energy systems installations in Europe in that year [1].

Due to the intermittent nature of wind and solar energy and this increased penetration of renewable energy sources, new solutions are being sought to enhance the reliability of electricity supply. Energy storage has been identified as one of solutions to limit the capacity of reserve generation needed and which also can defer the expansion of transmission and distribution assets [2]. Compressed Air Energy Storage (CAES) has been shown to be attractive for providing regulating reserve and levelling power imbalances hourly and daily [3, 4].

The economic and operational aspects of using compressed air as energy storage have been investigated by a number of researchers recently including: Wang and Yu [5], Succar et al [6], 
Sundararagavan and Baker [7], Marano et al [8], Abbaspour et al [9], Zafirakis et al [10], Madlener and Latz [11], and Fertig and Apt [12].

Wang and $\mathrm{Yu}$ [5] proposed an optimisation model for deciding the rated power and capacity of a CAES system to maximise profit. They conducted a case study of a system containing eight wind farms and concluded that properly sized energy storage system might be economically feasible.

Sundararagavan and Baker [7] conducted a comparative analysis of eleven energy storage technologies, including: electrochemical storage, flywheels, pumped hydro and CAES for integration with wind power generation. They found that the cost of the CAES was the lowest of the energy storage technologies considered.

The economic feasibility of CAES to improve wind power integration through a profitmaximizing algorithm was modelled by Madlener and Latz [11]. Using an economic model they evaluated three different systems: (1) a wind park without CAES; (2) a wind park with conventional centralized CAES in diabatic or adiabatic use; and (3) a wind park with integrated CAES in diabatic or adiabatic use. The research showed that, given the present conditions on the minute reserve market in Germany, CAES power plants are not economically feasible.

Similar conclusions were drawn by Fertig and Apt [12], who analysed the economics of CAES integrated with wind power. They modelled a $1300 \mathrm{MW}$ wind/CAES system located in central Texas with two loads $530 \mathrm{~km}$ and $320 \mathrm{~km}$ away. They reported that given 2007-2009 wind conditions, electricity prices, and gas prices the combined wind/CAES would not be economically viable.

One distinctive feature of CAES systems, compared with other energy storage technologies, is the production of a large quantity of heat during the compression stage. Similarly, during the expansion stage, the air is cooled. The cold air can be used later for cooling purposes. The use of this temperature change phenomenon of CAES was recently investigated by several researchers. 
Fiaschi et al [13] investigated an offshore power plant containing solar PV, wave energy conversion device and small vertical axis wind turbines, integrated with two different energy storage systems: CAES and hot rock bed energy storage. In their conceptual power plant model hot rock bed energy storage was used to store heat generated during compression and for preheating compressed air before expansion.

Kim et al $[14,15]$ conducted thermodynamic analysis of CAES with various configurations. They reviewed CAES technologies and analysed adiabatic and isothermal CAES systems using energy and exergy analysis. Thermodynamic analysis of advanced adiabatic CAES was also conducted by Zhang et al [16], who showed that an efficiency of around $75 \%$ could be achieved.

Research and development of CAES technologies has spurred interest among industrial companies. RWE has undertaken the first of its kind development project of Advanced Adiabatic CAES [17]. Heat generated during compression will be stored in a tank, which will be filled with solid heat energy storage material. According to RWE an energy efficiency of about $70 \%$ is expected.

Buffa et al [18] conducted exergy and exergoeconomic analysis of an adiabatic CAES system developed by GE Nuovo Pignone. It was found that the exergy efficiency of such systems was about 52\%. They also calculated the exergy costs of the electricity that was produced using an exergoeconomic approach. A cost of electricity at around $0.07 \varnothing / \mathrm{kWh}(70 € / \mathrm{MWh})$ was reported. Other interesting applications of CAES have been proposed [19-23]. Morandin et al [19, 20] analysed a novel thermo-electrical energy storage (TEES) system based on hot water, ice storage and a transcritical $\mathrm{CO}_{2}$ cycle. They showed that the maximum roundtrip efficiency of such TEES can be around $60 \%$.

Kim and Favrat performed energy and exergy analysis of constant pressure air micro-CAES with an air heating and cooling system [21]. They analysed eight different configurations of microCAES. An exergy efficiency between $34 \%$ and $74 \%$ was found. They concluded that the exergy 
efficiency is highest, using quasi-isothermal compression and expansion, when liquid is injected during the compression and expansion processes.

Li et al in their study investigated a small scale CAES system based on a refrigeration cycle, which can be used for generation of electricity, heating and cooling for domestic households and small office buildings [22]. They proposed the concept of comprehensive efficiency, and showed that the comprehensive efficiency of such combined system can be around $50 \%$ in winter and $35 \%$ in summer.

Safaei et al [23] proposed to distribute the compressors of a CAES system near heat loads to enable the recovery of heat in order to supply heating using district heating networks. In the study they analysed conventional CAES and Distributed CAES systems. From their optimisation analysis, these researchers concluded that the distance between heat load and storage site has a critical impact on the economics of Distributed CAES systems. They reported that the Distributed CAES with a maximum air pipeline distance of $100 \mathrm{~km}$ between the compressor and air storage cavern may be feasible at a minimum effective fuel price of $8.3 \$ / G J$.

The objective of the study reported in this paper was to analyse the potential for using heat generated during the compression stage in Compressed Air Energy Storage system using exergy and exergoeconomic analysis. Two systems were investigated: Compressed Air Energy Storage (CAES) and the same size Compressed Air Energy Storage combined with Thermal Storage (CAES-TS). In the second system, heat generated during the compression cycle was used to charge thermal energy storage systems, connected to a district heating network.

The Specific Exergy Costing (SPECO) method [24] was used to conduct exergoeconomic analysis. The exergy destruction costs in CAES systems were determined and the exergy costs of heat and electricity were calculated. The variations of exergy costs depending on the electricity and fuel costs were also investigated. 


\section{Operation of Compressed Air Energy Storage system}

Models of Compressed Air Energy Storage System (CAES) and Compressed Air Energy Storage combined with Thermal Storage (CAES-TS) were built based on the conventional CAES system developed by Dresser Rand [25]. The only difference between these systems is that the heat generated during the compression process is not stored using the CAES. In the CAES system the compressed air stream is cooled using circulating water that is pumped to a cooling tower and released to atmosphere.

The Cycle-Tempo (Release 5) modelling software [26] was used for modelling air compression and expansion processes. Cycle-Tempo is a graphical tool for thermodynamic analysis and optimisation of energy systems. Using this tool all mass, energy and exergy flows in energy system are calculated. Using Cycle-Tempo comprehensive thermodynamic analysis including energy and exergy analyses can be conducted.

Air Storage cavern (AS) and Thermal Storage tank (TS) models were developed using Matlab (R2010a)/Simulink (v7.5). A schematic drawing of the CAES-TS system is presented in Fig. 1.

The CAES-TS system consists of four main subsystems: compression stage, expansion stage, compressed air storage (AS) and thermal storage (TS). The CAES-TS operates in two regimes: compression mode and expansion modes. During periods of surplus electricity generation, air is pressurised using the compressors and stored in the underground cavern. Heat generated during the compression stage is stored in thermal storage tanks, connected to a district heating system. When the demand for electricity is high, compressed air is used to generate electricity. The compressed air is preheated in the heat exchangers and combustors, and expands in the turbines. It is assumed that compression and expansion cycles occur at constant mass flow rate and pressure.

Four compressors (components 1, 3,5 and 7 in Fig. 1) are used to pressurise air from ambient pressure to about 82 bar pressure. In the first compression stage (compressor 1) the air is 
pressurised to about 4.5 bar pressure. After this compression the air temperature increases to about $210^{\circ} \mathrm{C}$. Air is cooled in the heat exchanger (2, Fig. 1) to about $50^{\circ} \mathrm{C}$ and enters the next compressor. In the second, third and fourth stages (compressors 3, 5 and 7, Fig. 1) air is compressed to 16,41 and 82 bar pressure. The compressed air temperature rises to $220^{\circ} \mathrm{C}$ after the second compressor, $170^{\circ} \mathrm{C}$ after the third compressors and $140^{\circ} \mathrm{C}$ after the fourth compressor. After each compression stage the air is cooled to $50^{\circ} \mathrm{C}$ in heat exchangers $(4,6$ and 8, Fig. 1). Finally compressed air at 82 bar pressure and about $50^{\circ} \mathrm{C}$ is stored in an underground cavern.

Water is used for cooling the compressed air. During the compression stage water circulates through the heat exchangers $(2,4,6$ and 8, Fig. 1) and reduces the temperature of the air. Heated water is used to charge a thermal storage tank. The supply and return water temperatures from the TS system are assumed to be $40^{\circ} \mathrm{C}$ and $90^{\circ} \mathrm{C}$. The TS tank is connected to a District Heating network.

During the expansion stage, compressed air is throttled using valve (26, Fig. 1), preheated in heat exchanger (21, Fig. 1) to about $400^{\circ} \mathrm{C}$ and delivered to a combustor (22, Fig. 1). Natural gas is used for combustion. After the combustor (22, Fig. 1) the mixture of compressed air and burned gases enters the first gas turbine (23, Fig. 1). Exhaust gas mixture is supplied then to a second combustor (24, Fig. 1) where it is heated to about $870^{\circ} \mathrm{C}$ at 17 bar pressure. Hot gas is delivered to a second gas turbine (25, Fig. 1) where it expands. Finally hot gas at a temperature of around $430^{\circ} \mathrm{C}$ after the gas turbines is used to preheat the incoming compressed air stream in a heat exchanger (21, Fig. 1). The temperature of the hot gas stream after the heat exchanger (component 21, pipeline 27, Fig. 1) drops to about $75^{\circ} \mathrm{C}$. Due to the low temperature this stream was not suitable for energy storage. All calculations have been performed at constant $+15^{\circ} \mathrm{C}$ (288 K) ambient temperature and $101.3 \mathrm{kPa}$ pressure. Simulation data of CAES-TS are presented in Table 1. 


\subsection{Compressed Air Storage model}

An underground cavern model developed by Raju and Khaitan [27] was used to investigate the pressure and temperature variations in the cavern and to estimate the operation time of the compressors and turbines. The mass balance for the air storage cavern is described using equation:

$$
\frac{d \rho}{d t}=\frac{\dot{m}_{\text {in }}-\dot{m}_{\text {out }}}{V}
$$

The energy balance for the air cavern is given using first order differential equation:

$$
\rho c_{p} \frac{d T_{a i r}}{d t}+\frac{\dot{m}_{\text {in }}}{V} c_{p}\left(T_{\text {air }}-T_{\text {air }, \text { in }}\right)-\frac{d P}{d t}+h_{e f f}\left(T_{\text {air }}-T_{\text {wall }}\right)=0
$$

Here $h_{\text {eff }}$ is effective heat transfer coefficient. The effective heat transfer coefficient was calculated using equation [27]:

$$
h_{e f f}=0.2356+0.0149\left|\dot{m}_{i}-\dot{m}_{e}\right|^{0.8}
$$

The underground air storage model was built using Matlab (R2010a)/Simulink (v7.5).

It was assumed that the volume of the cavern was $300000 \mathrm{~m}^{3}$. A constant mass flow rate during the compression and expansion processes was maintained. The minimum operating pressure in the cavern was 50 bar and the maximum 82 bar.

It was assumed that the expansion process started seven hours after the full compression process had been completed, and the compression started five hours after the full expansion process was completed. A full compression-expansion cycle lasted almost 48 hours. Based on these assumptions the total operating times of the CAES-TS and CAES were found. The operating time of the compression process was 2747 hours per year, and the operating time of the expansion was 3801 hours per year. This data was used to conduct exergoeconomic analysis.

Temperature and pressure variations in the cavern are shown in Fig. 2. It is seen that due to the constant mass flow rate, the pressure in the cavern increases linearly. Due to the expansion and 
compression processes, the temperature in the cavern varied between 280 and $320 \mathrm{~K}$. Constant cavern wall temperature at $295 \mathrm{~K}$ was assumed in this study. When air was compressed the temperature increased above $295 \mathrm{~K}$. When air was extracted from the storage, the temperature dropped below $295 \mathrm{~K}$. Therefore, due to the heat transfer between the compressed air and ground temperature the temperature change was observed during the standby periods.

\subsection{Thermal Energy Storage model}

Sensible heat storage using water as a heat transfer fluid was assumed in this study. The heat storage was connected to a District Heating network. Stratified heat storage tank model using seven nodes (layers) was built using Matlab (R2010a)/Simulink (v7.5). Mathematical model of a stratified heat storage tank is described using first order ordinary differential equation [28]:

$$
\begin{gathered}
\rho V_{i} c_{p} \frac{d T_{s, i}}{d t}=\delta_{i}^{c}\left(\dot{m} c_{p}\right)_{c}\left(T_{c, o u t}-T_{s, i}\right)-\delta_{i}^{d h}\left(\dot{m} c_{p}\right)_{d h}\left(T_{s, i}-T_{d h, r e t}\right)- \\
U A_{i, w}\left(T_{s, i}-T_{a}\right)+\delta_{i}^{+} \dot{m}_{i} c_{p}\left(T_{s, i-1}-T_{s, i}\right)+\delta_{i}^{-} \dot{m}_{i+1} c_{p}\left(T_{s, i}-T_{s, i+1}\right)+ \\
A_{q} \frac{\lambda_{e f f}}{Z}\left(T_{s, i}-T_{s, i-1}\right)
\end{gathered}
$$

Where $\lambda_{\text {eff }}$ is effective heat conductivity $0.644 \mathrm{~W} /(\mathrm{mK})$ [28]. Effective mass flow rates $\dot{m}_{i}$ are calculated using equations:

$$
\begin{aligned}
& \dot{m}_{i}=\dot{m}_{c}-\dot{m}_{l}, \text { for } \mathrm{i}=2 \ldots 6 \\
& \dot{m}_{i}=0, \text { for } \mathrm{i}=1 \text { and } 7
\end{aligned}
$$

Switching coefficients $\delta_{i}^{c}, \delta_{i}^{d h}, \delta_{i}^{+}$and $\delta_{i}^{-}$are defined:

$$
\begin{aligned}
& \delta_{i}^{c}=1 \text { if } i=1 ; \quad \delta_{i}^{c}=0 \text { if } i \neq 1 \\
& \delta_{i}^{d h}=1 \text { if } i=7 ; \quad \delta_{i}^{d h}=0 \text { if } i \neq 7 \\
& \delta_{i}^{+}=1 \text { if } \dot{m}_{i}>0 ; \quad \delta_{i}^{+}=0 \text { if } \dot{m}_{i} \leq 0
\end{aligned}
$$




$$
\delta_{i}^{-}=1 \text { if } \dot{m}_{i+1}<0 ; \quad \delta_{i}^{-}=0 \text { if } \dot{m}_{i+1} \geq 0
$$

Three water tanks of $20000 \mathrm{~m}^{3}$ each were assumed. The connection and operation scheme is depicted in Fig. 3. It is assumed that each tank is charged in turn when the compression process is started. Each compression cycle lasts approximately 15 hours. Therefore, it takes approximately 5 hours to charge each water storage tank. When the first tank is fully charged, the charging of the next water tank begins. Meanwhile, the discharge process of the first water tank, which is connected to the DH network, begins. The discharge stage of the second tank is postponed until the first tank is discharged. The process is repeated for each tank in sequence. The operating pattern of the heat storage system is shown in Fig. 4. In Fig 4, the temperature of the top layer of the stratified tank is shown as a bold line, and the temperature of the bottom layer is presented as the dotted line.

\section{Energy and exergy efficiency analysis}

Energy and exergy efficiencies of CAES and CAES-TS systems including auxiliary pump power are shown in Table 2. The energy and exergy efficiency of the CAES is identical to the electrical efficiencies of the CAES-TS. The energy efficiencies were calculated using equation:

$$
\eta=\frac{\dot{Q} \cdot t_{c h}+\dot{W}_{t u r} \cdot t_{d i s}}{\dot{W}_{c} \cdot t_{c h}+\dot{m} \cdot H H V \cdot t_{d i s}}=\frac{Q+W_{t u r}}{W_{c}+F}
$$

For the CAES case, where heat was not utilised, it was assumed that $\dot{Q}=0$. The same assumption is taken when electrical efficiency of the CAES-TS is calculated.

The exergy efficiencies were calculated using equation:

$$
\psi=\frac{\dot{E}_{q} \cdot t_{c h}+\dot{E}_{t u r} \cdot t_{d i s}}{\dot{E}_{c} \cdot t_{c h}+\dot{m} \cdot e \cdot t_{d i s}}=\frac{E_{q}+E_{t u r}}{E_{c}+E_{f}}
$$

For the CAES case it was assumed that $\dot{E}_{q}=0$.

It is seen from Table 2 that the energy efficiency of the CAES-TS (85.8\%) is considerably higher compared with CAES system (48.4\%). The exergy efficiency of CAES-TS is $55.8 \%$ and CAES 
is $50.1 \%$. Using the CAES-TS system small increase in exergy efficiency occurs. It is related to the low exergy $E_{q}$ associated with heat. Small increase of $E_{q}$ has little effect on overall exergy efficiency.

\section{Exergoeconomic analysis}

The Specific Exergy Costing (SPECO) method [24] was used in this study. The method consists of three steps:

- Identification of exergy streams;

- Definition of products and fuels;

- Construction of cost equations.

The first step was carried out using Cycle-Tempo software. Fuels and products of each system were found using the definitions proposed by Tsatsaronis [29, 30]. Finally the construction of cost equations was carried out. This consists of two parts. First the exergy cost equation for each component of the system is composed. The general form of this equation for the $k$-th component is:

$$
\sum\left(c_{\text {out }} \dot{E}_{\text {out }}\right)_{k}+c_{w, k} \dot{W}_{k}=c_{q, k} \dot{E}_{q, k}+\sum\left(c_{\text {in }} \dot{E}_{\text {in }}\right)_{k}+\dot{Z}_{k}
$$

Here $c_{\text {out }}, c_{i n}, c_{q}, c_{w}$ are the average costs per unit of exergy; $\dot{E}_{\text {out }}, \dot{E}_{\text {in }}, \dot{E}_{q}, \dot{W}_{k}$ are the exergy streams an power, and $\dot{Z}_{k}$ is the sum of capital investments costs.

Cost streams $\dot{C}$ associated with the corresponding exergy streams are calculated using equations:

$$
\begin{aligned}
& \dot{C}_{\text {out }}=c_{\text {out }} \dot{E}_{\text {out }} \\
& \dot{C}_{\text {in }}=c_{\text {in }} \dot{E}_{\text {in }}
\end{aligned}
$$

However, there were more streams than devices. Therefore, auxiliary equations were formulated using principles of the SPECO method [24]. Equations associated with the exergy streams supplied to the systems from outside and auxiliary equations provided the required number of equations to find the specific costs of the streams. The final exergy costs of products were found by solving the system of equations, which consisted of main and auxiliary equations. More detailed description of the application of SPECO method can be found elsewhere [31]. 
Capital costs of the CAES-TS system components were taken from the report "Compressed Air Energy Storage scoping study for California" [32]. The cost of thermal storage equipment was calculated using the costs provided in the "Process Equipment Cost Estimation" report [33]. For the CAES system without the thermal storage a cooling tower was designed instead of the water tanks. The cost of the cooling tower was taken from the "Process Equipment Cost Estimation" report [33]. The total cost of the CAES-TS including construction and electrical installation costs was $€ 76.4$ million, and $€ 73.7$ million for the CAES.

The following assumptions were made for both CAES systems:

- $10 \%$ return on investment,

- 20 years investment repayment period,

- 2747 annual operating hours in compression mode,

- 3801 annual operating hours in expansion mode,

- operation and maintenance costs are not included,

- $2.86 \notin / \mathrm{kWh}$ fuel price (HHV based) for natural gas for industrial consumers in UK in 2012, taken from EU Energy Portal (www.energy.eu).

- $9.895 \varnothing / \mathrm{kWh}$ electricity price in UK, taken from EU Energy Portal (www.energy.eu).

The calculated exergy cost of electricity $9.90 \phi / \mathrm{kWh}$ and exergy cost of natural gas $3.07 \phi / \mathrm{kWh}$ was used in this study.

\subsection{Compressed Air Energy Storage with Thermal Storage (CAES-TS)}

Using the exergoeconomic approach the cost rates of exergy destruction and capital cost rates of the CAES-TS system were calculated. The results of this calculation for the elements of the compression and expansion stages are shown in Fig. 5.

The cost rates of exergy destruction in heat exchangers 2 and 4 (HEX 2 and HEX 4) in the compression stage are the highest (Fig. 5). The cost rate of exergy destruction in heat exchanger 2 is $473 € / \mathrm{h}$ and in heat exchanger 4 is $570 € / \mathrm{h}$. The reason is the relatively high temperature difference between the gas after the compressors (1 and 3) and cooling water. In the compression 
stage, heat exchangers and compressors are the main system components where exergy destruction occurs.

In the expansion stage (Fig. 5) the highest exergy destruction is observed in combustor 24, gas turbine 25 , throttling valve and heat exchanger 21 . High exergy destruction in combustor 24 is related to high fuel consumption. About $75 \%$ of the fuel is used in combustor 24; consequently about $75 \%$ of electricity is generated in turbine 25 . Therefore, exergy destruction in combustor 24 and turbine 25 is high compared with combustor 22 and turbine 23 . A very high cost of exergy destruction, about $700 € / \mathrm{h}$, is observed in the throttling valve, which is used to control air pressure before the gas turbines. A variable pressure system would be desirable as it allows unnecessary exergy destruction in pressure reduction devices to be avoided.

\subsection{Compressed Air Energy Storage (CAES)}

The main difference between the CAES-TS and CAES is that, using the CAES system, the heat generated during the compression stage is released to atmosphere and wasted. Therefore, the exergy cost equations are constructed so that the exergy cost of heat is apportioned to the compressed air stream in each heat exchanger (2, 4, 6 and 8 in Fig. 1) in the compression stage. The exergy cost of compressed air in the CAES is higher than in the CAES-TS, thus the exergy destruction cost rate increases in almost all components of the expansion stage.

Results of exergoeconomic analysis of the CAES system without thermal storage are presented in Fig. 6. Similarly to the CAES-TS system, the exergy destruction cost rates are the highest in the heat exchangers, combustor, gas turbine and throttling valve. It is seen from Fig. 6 that the exergy destruction rate, using CAES, increases in almost all components in the expansion stage (except combustors 22 and 24) compared with the CAES-TS. The augmentation of the exergy destruction cost rate in heat exchanger 21 by $24 \%$, in turbine 23 by $34 \%$, in turbine 25 by $24 \%$ and in the throttling valve by $43 \%$ using the CAES is observed compared with the CAES-TS. The reason for that is the higher exergy cost of compressed air. The exergy destruction costs in 
the combustors do not increase, because they depend only on the fuel exergy cost. Fuel consumption is the same in both systems, thus the exergy destruction cost rate does not change.

\subsection{Exergy costs of products}

Exergy costs of heat and electricity were calculated with results shown in Fig. 7. The electricity energy cost is $9.90 \phi / \mathrm{kWh}$, and the energy cost of natural gas is $2.86 \phi / \mathrm{kWh}$.

The energy and exergy of electricity are equal and the energy and exergy costs are also the same. As the exergy of natural gas is lower than the Higher Heating Value, the calculated exergy cost of the gas is $3.07 \mathrm{c} / \mathrm{kWh}$.

In the CAES-TS system during the compression stage the two outputs are produced: compressed air and heat. Compressed air is stored and later used for electricity generation during the expansion stage. The exergy cost of compressed air is $12.18 \phi / \mathrm{kWh}$ and the exergy cost of heat is $22.24 \phi / \mathrm{kWh}$. The exergy cost of electricity after the expansion stage is $11.20 \phi / \mathrm{kWh}$. This corresponds to an increase of electricity cost by about $13 \%$ compared with the initial cost of electricity used for the compression. The exergy cost of generated electricity is lower than the cost of the compressed air, which is used to generate electricity. The reason for that is the relatively low contribution of compressed air to the electricity generation. The main source of energy in the expansion stage is natural gas whose cost is significantly lower than that of compressed air.

In the CAES system the only product during the compression stage is compressed air. Cooling of the compressors is necessary and all heat is rejected to the atmosphere. As heat is not a product, its exergy cost is apportioned to the cost of the compressed air stream. In the CAES the exergy cost of compressed air increases by $43 \%$ to $17.42 \phi / \mathrm{kWh}$, compared to the exergy cost of air in the CAES-TS system. Consequently the electricity exergy cost increases by about $40 \%$ to 13.89 $\phi / \mathrm{kWh}$ compared with the initial electricity cost. 
An average weighted cost of exergy (combined exergy cost of electricity and natural gas) used for storing energy in CAES-TS is about $6.32 ф / \mathrm{kWh}$. The final exergy cost of generated electricity is $11.20 \phi / \mathrm{kWh}$ for the CAES-TS and $13.89 \phi / \mathrm{kWh}$ for the CAES. An increase of the exergy cost of electricity by about $78 \%$ for the CAES-TS and by $120 \%$ for the CAES is observed compared with the initial exergy costs of electricity and natural gas.

\section{Effect of the variation of fuel energy prices}

Variations of the price of fuel and electricity have a significant impact on the exergy costs of heat and elctricity. The relationship between the fuel energy prices and exergy costs for CAESTS and CAES systems is presented in Fig. 8a and 8b.

Fig 8 a shows that, due to the increased prices of gas and electricity, the exergy costs of products increases linearly. As heat is generated during the compression stage in CAES-TS system its exergy cost depends only on the electricity price. Similar results are observed in Fig. 8b for CAES system.

\section{Conclusion}

The potential for using waste heat generated during the compression stage in Compressed Air Energy Storage systems was investigated. Two CAES systems were analysed using exergy and exergoeconomic analysis including CAES system and CAES with sensible Thermal Storage (CAES-TS) connected to a district heating network.

The maximum power output of the CAES was $100 \mathrm{MWe}$ and the power output of the CAES-TS was $100 \mathrm{MWe}$ and the heat output was $105 \mathrm{MWth}$. The study shows that $308 \mathrm{GWh}$ of electricity and $466 \mathrm{GWh}$ of fuel are used to generate $375 \mathrm{GWh}$ of electricity per year. During the compression of the air $289 \mathrm{GWh} /$ year of heat is generated. This heat is released to atmosphere and wasted using the CAES system. Due to the utilisation of waste heat the energy efficiency increases from $48 \%$ for the CAES to almost $86 \%$ for the CAES-TS system. 
The exergy analysis shows that the exergy efficiency of CAES-TS is $55.8 \%$ and CAES is $50.1 \%$. The highest exergy destruction occurs in the heat exchangers during the compression stage. The reason for high exergy destruction is the relatively high temperature difference between the compressed air and water. Due to the high temperature of the compressed air other energy storage technologies could potentially be used, for example, latent thermal energy storage. In the expansion stage the largest exergy destruction is observed in the combustors and turbines.

Using exergoeconomic analysis, electricity and heat exergy costs were calculated for both systems. It was found that the exergy cost of electricity was $11.20 \phi / \mathrm{kWh}$ for the CAES-TS and $13.89 \phi / \mathrm{kWh}$ for the CAES systems. The heat exergy cost was $22.24 \phi / \mathrm{kWh}$ in the CAES-TS system.

A large amount of heat is wasted and a large amount of gas consumed in CAES systems. The study shows that the Compressed Energy Storage systems combined with Thermal Storage has the potential for being used as energy storage and as a heat source for district heating systems. Due to the intermittent nature of wind and solar energy CAES-TS could be used as a tool for balancing overall energy demand and supply. However, more research is required to analyse how gas can be replaced with renewable energy and develop new CAES-TS systems. Such modified combined energy storage systems could be used for energy storage, heating and cooling of residential and commercial buildings.

\section{Acknowledgments}

This research formed part of the programme of the UK Energy Research Centre and was supported by the UK Research Councils under Natural Environment Research Council award (NE/G007748/1) (Phase II) and by the Higher Education Funding Council for Wales (HEFCW).

\section{References}

[1] Wilkes J, Moccia J. Wind in power: 2012 European Statistics. EWEA; 2013. p. 14. 
[2] Drury E, Denholm P, Sioshansi R. The value of compressed air energy storage in energy and reserve markets. Energy. 2011;36(8):4959-73.

[3] Cavallo A. Controllable and affordable utility-scale electricity from intermittent wind resources and compressed air energy storage (CAES). Energy. 2007;32:120-7.

[4] Hedegaard K, Meibom P. Wind power impacts and electricity storage - A time scale perspective. Renewable Energy. 2012;37(1):318-24.

[5] Wang SY, Yu JL. Optimal sizing of the CAES system in a power system with high wind power penetration. International Journal of Electrical Power and Energy Systems. 2012;37(1):117-25.

[6] Succar S, Denkenberger DC, Williams RH. Optimization of specific rating for wind turbine arrays coupled to compressed air energy storage. Applied Energy. 2012;96:222-34.

[7] Sundararagavan S, Baker E. Evaluating energy storage technologies for wind power integration. Solar Energy. 2012;86(9):2707-17.

[8] Marano V, Rizzo G, Tiano FA. Application of dynamic programming to the optimal management of a hybrid power plant with wind turbines, photovoltaic panels and compressed air energy storage. Applied Energy. 2012;97:849-59.

[9] Abbaspour M, Satkin M, Mohammadi-Ivatloo B, Hoseinzadeh Lotfi F, Noorollahi Y. Optimal operation scheduling of wind power integrated with compressed air energy storage (CAES). Renewable Energy. 2013;51:53-9.

[10] Zafirakis D, Chalvatzis KJ, Baiocchi G, Daskalakis G. Modeling of financial incentives for investments in energy storage systems that promote the large-scale integration of wind energy. Applied Energy. 2013;105:138-54.

[11] Madlener R, Latz J. Economics of centralized and decentralized compressed air energy storage for enhanced grid integration of wind power. Applied Energy. 2013;101:299-309.

[12] Fertig E, Apt J. Economics of compressed air energy storage to integrate wind power: A case study in ERCOT. Energy Policy. 2011;39(5):2330-42. 
[13] Fiaschi D, Manfrida G, Secchi R, Tempesti D. A versatile system for offshore energy conversion including diversified storage. Energy. 2012;48(1):566-76.

[14] Kim YM, Lee JH, Kim SJ, Favrat D. Potential and evolution of compressed air energy storage: Energy and exergy analyses. Entropy. 2012;14(8):1501-21.

[15] Kim YM, Shin DG, Favrat D. Operating characteristics of constant-pressure compressed air energy storage (CAES) system combined with pumped hydro storage based on energy and exergy analysis. Energy. 2011;36(10):6220-33.

[16] Zhang Y, Yang K, Li X, Xu J. The thermodynamic effect of air storage chamber model on Advanced Adiabatic Compressed Air Energy Storage System. Renewable Energy. 2013;57:46978.

[17] RWE project ADELE http://www.rwe.com/web/cms/en/365478/rwe/innovation/projectstechnologies/energy-storage/project-adele-adele-ing/ [accessed 25.05.2013].

[18] Buffa F, Kemble S, Manfrida G, Milazzo A. Exergy and exergoeconomic model of a ground-based CAES plant for peak-load energy production. Energies. 2013;6(2):1050-67. [19] Morandin M, Maréchal F, Mercangöz M, Buchter F. Conceptual design of a thermoelectrical energy storage system based on heat integration of thermodynamic cycles - Part B: Alternative system configurations. Energy. 2012;45(1):386-96.

[20] Morandin M, Maréchal F, Mercangöz M, Buchter F. Conceptual design of a thermoelectrical energy storage system based on heat integration of thermodynamic cycles - Part A: Methodology and base case. Energy. 2012;45(1):375-85.

[21] Kim YM, Favrat D. Energy and exergy analysis of a micro-compressed air energy storage and air cycle heating and cooling system. Energy. 2010;35(1):213-20.

[22] Li Y, Wang X, Li D, Ding Y. A trigeneration system based on compressed air and thermal energy storage. Applied Energy. 2012;99:316-23.

[23] Safaei H, Keith DW, Hugo RJ. Compressed air energy storage (CAES) with compressors distributed at heat loads to enable waste heat utilization. Applied Energy. 2013;103:165-79. 
[24] Lazzaretto A, Tsatsaronis G. SPECO: A systematic and general methodology for calculating efficiencies and costs in thermal systems. Energy. 2006;31:1257-89.

[25] Compressed Air Energy Storage.

[26] Cycle-Tempo Release 5. Delft University of Technology; 1980-2007.

[27] Raju M, Khaitan SD. Modelling and simulation of compressed air storage in caverns: A case study of the Huntorf plant. Applied Energy. 2012;89:474-81.

[28] Eicker U. Solar Technologies for Buildings: Wiley, 2003.

[29] Tsatsaronis G. Thermoeconomic Analysis and Optimization of Energy Systems. Progress in Energy and Combustion Science. 1993;19:227-57.

[30] Bejan A, Tsatsaronis G, Moran M. Thermal Design and Optimization. New York: A WileyInterscience Publication, 1996.

[31] Bagdanavicius A, Jenkins N, Hammond GP. Assessment of community energy supply systems using energy, exergy and exergoeconomic analysis. Energy. 2012;45(1):247-55.

[32] Schainker RB, Rao A. Compressed Air Energy Storage scoping study for California, USA. California Energy Commission, PIER Energy-Related Environmental Research Program. CEC500-2008-069; 2008.

[33] Loh HP, Lyons J, White CW. Process Equipment Cost Estimation. Final Report. DOE/NETL-2002/1169

U.S. Department of Energy, National Energy Technology Laboratory; 2002. 


\section{List of figure captions}

1. Fig. 1. Compressed Air Energy Storage system combined with Thermal Storage

2. Fig. 2. Temperature and pressure variation in air storage cavern during compression and expansion

3. Fig. 3. Connection of thermal storage tanks

4. Fig. 4. Charging and discharging cycles of thermal storage tanks

5. Fig. 5. Exergoeconomic analysis of CAES-TS system

6. Fig. 6. Exergoeconomic analysis of CAES system

7. Fig. 7. Exergy costs of products

8. Fig. 8. Variation of exergy costs of products depending on fuel prices

\section{List of tables}

1. Table 1. Simulation data of CAES-TS

2. Table 2.Energy and exergy efficiency of the CAES-TS 


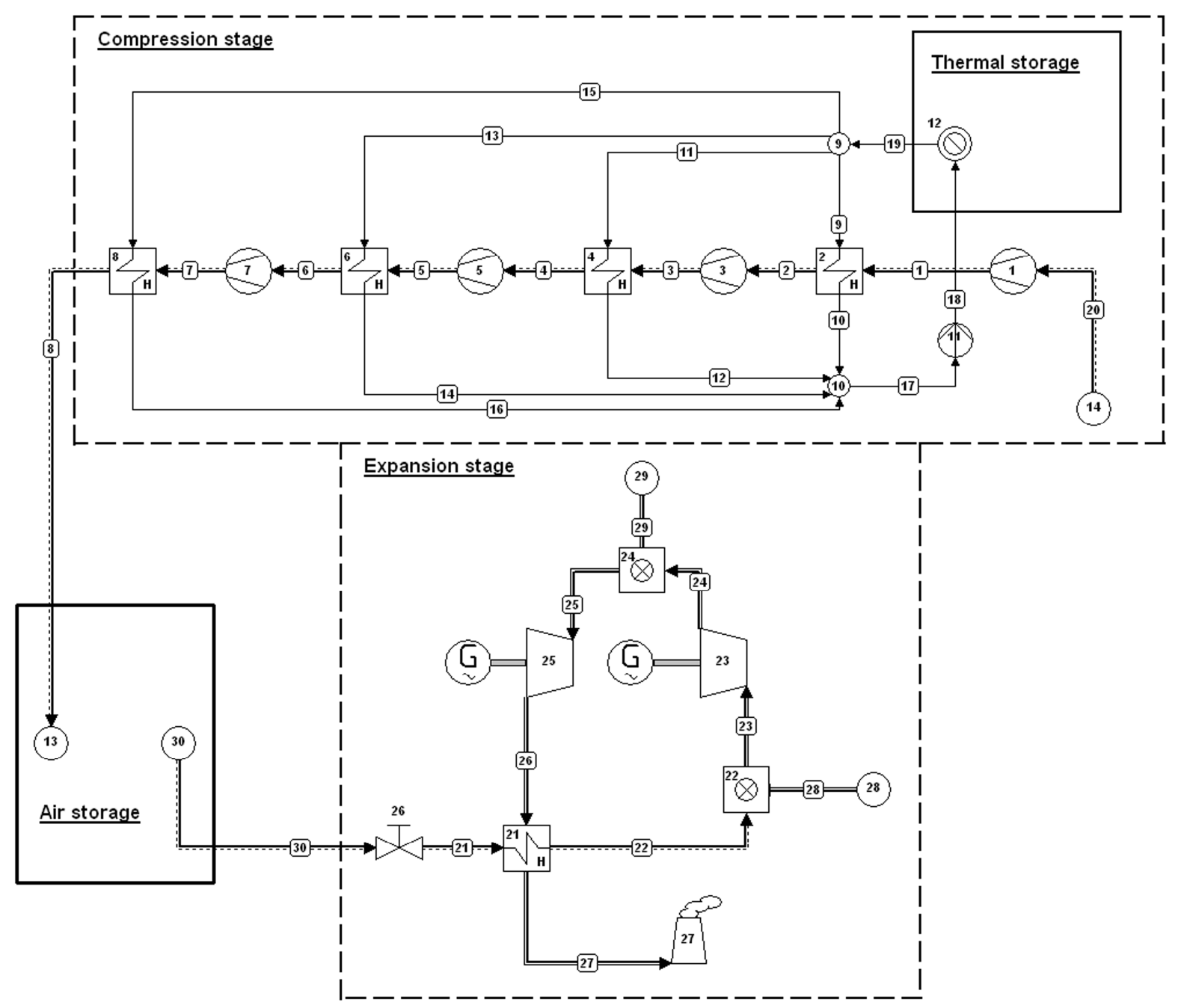

Fig. 1. Compressed Air Energy Storage system combined with Thermal Storage (1, 3, 5, 7 compressors; 2, 4, 6, 8, 21 - heat exchangers; 12 - thermal storage; 22, 24 - combustors; 23, 25 - gas turbines; 26 - throttle valve) 


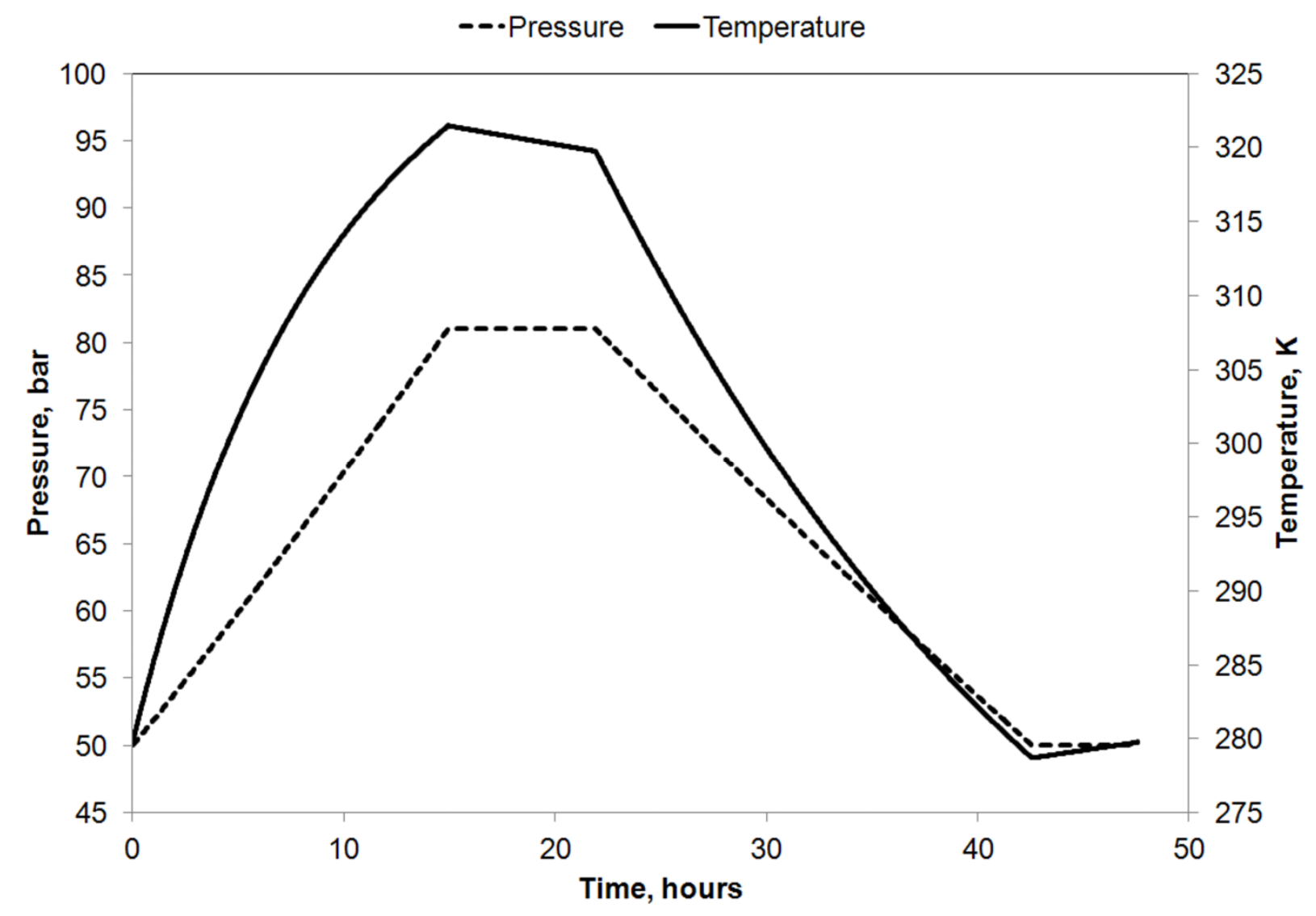

Fig. 2. Temperature and pressure variation in the air storage cavern during compression and expansion (one cycle) 


\section{From compressors}

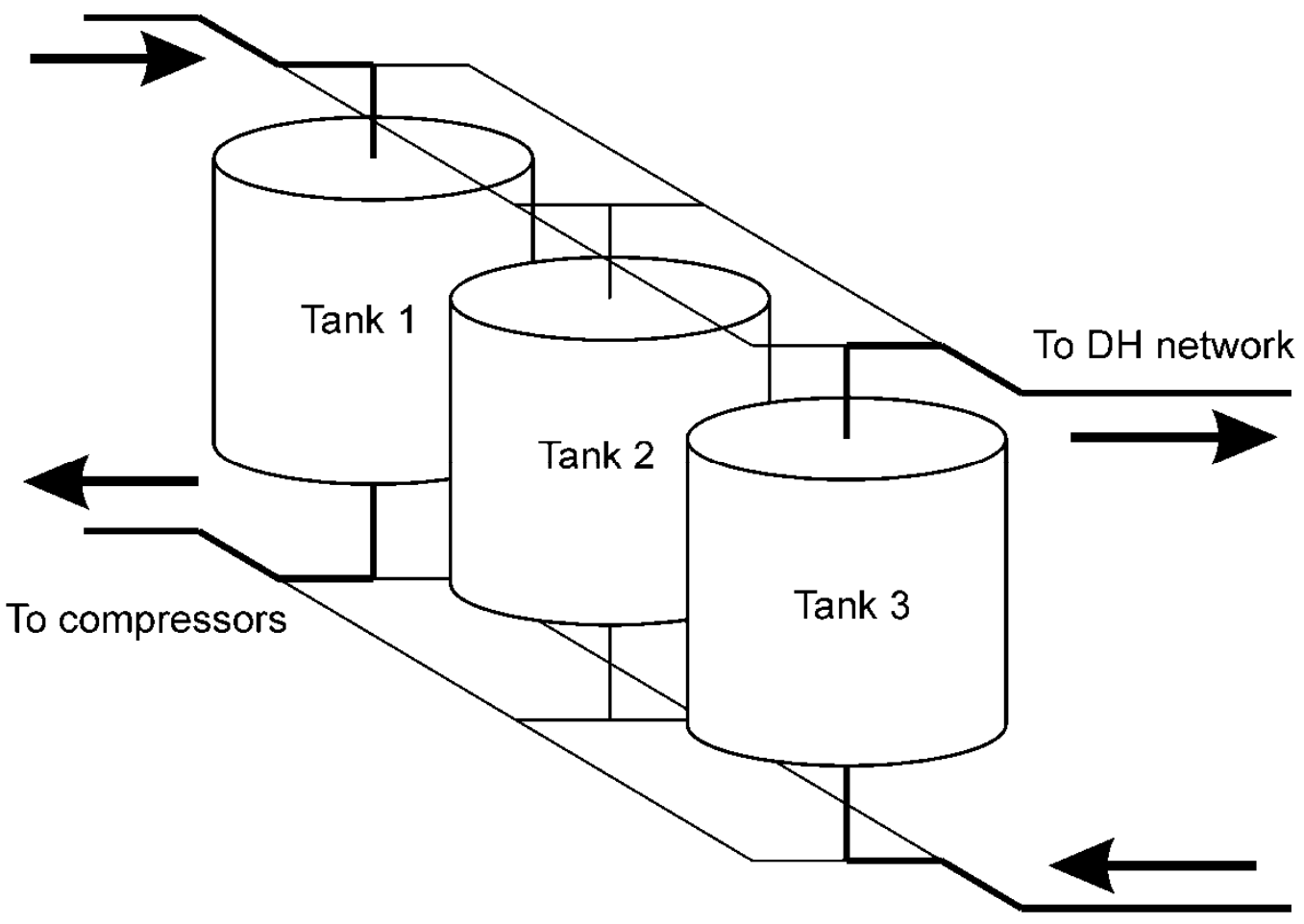

From DH network

Fig. 3. Connection of thermal storage tanks (Bold lines show flow streams, in this case the first tank is charging, the third tank is discharging, the second tank is not operating) 


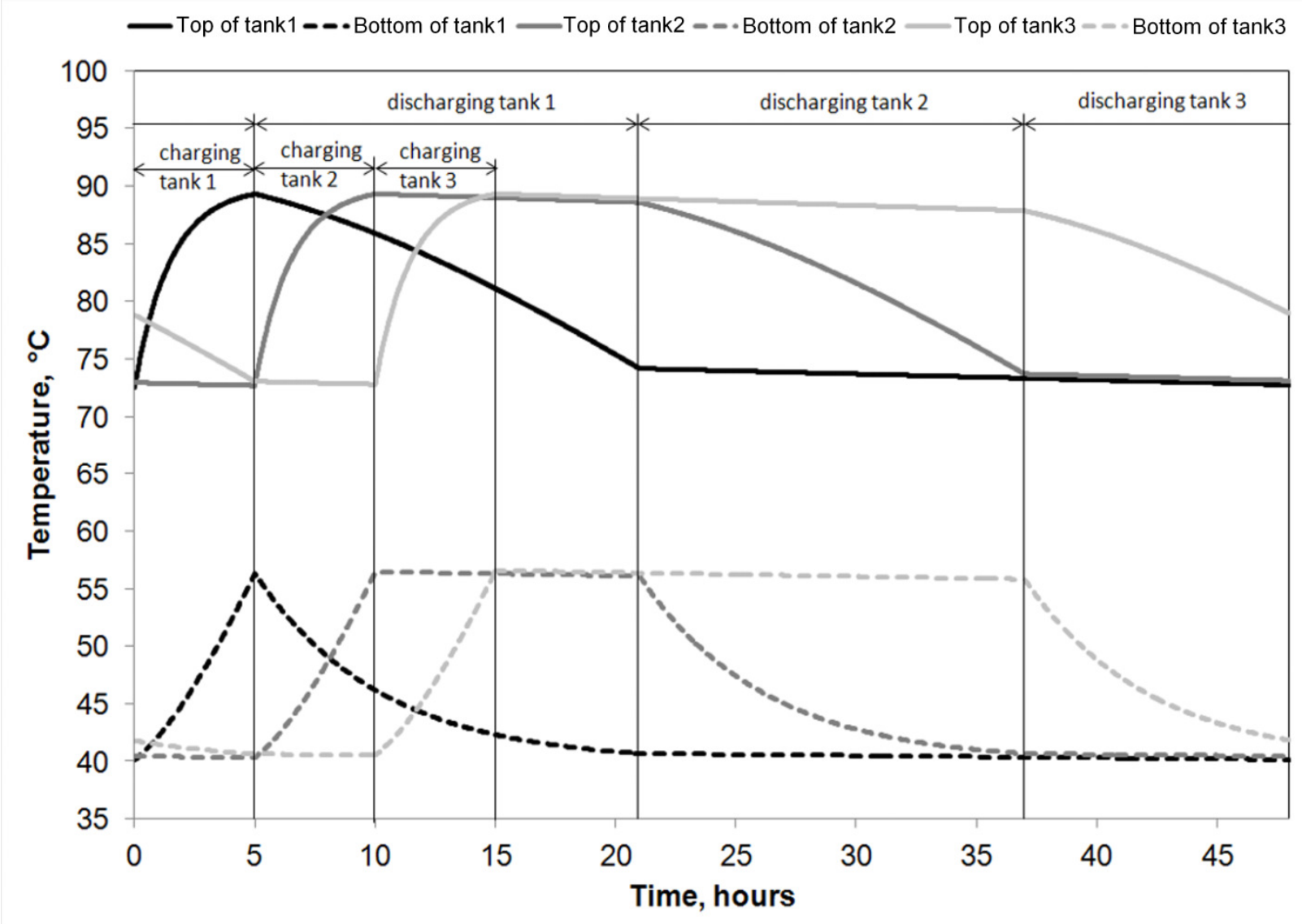

Fig. 4. Charging and discharging cycles of thermal storage tanks 


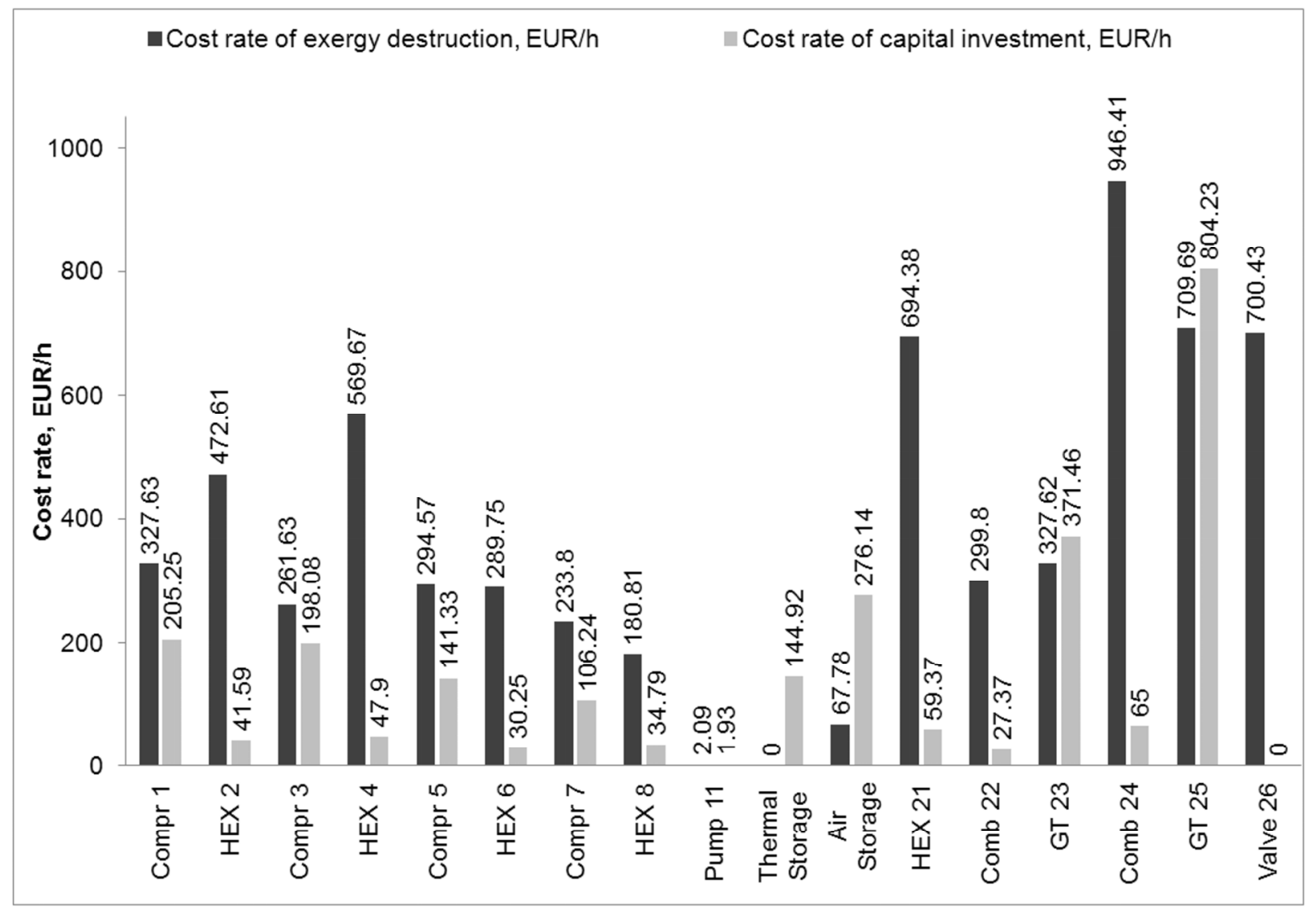

Fig. 5. Exergoeconomic analysis of CAES-TS system 


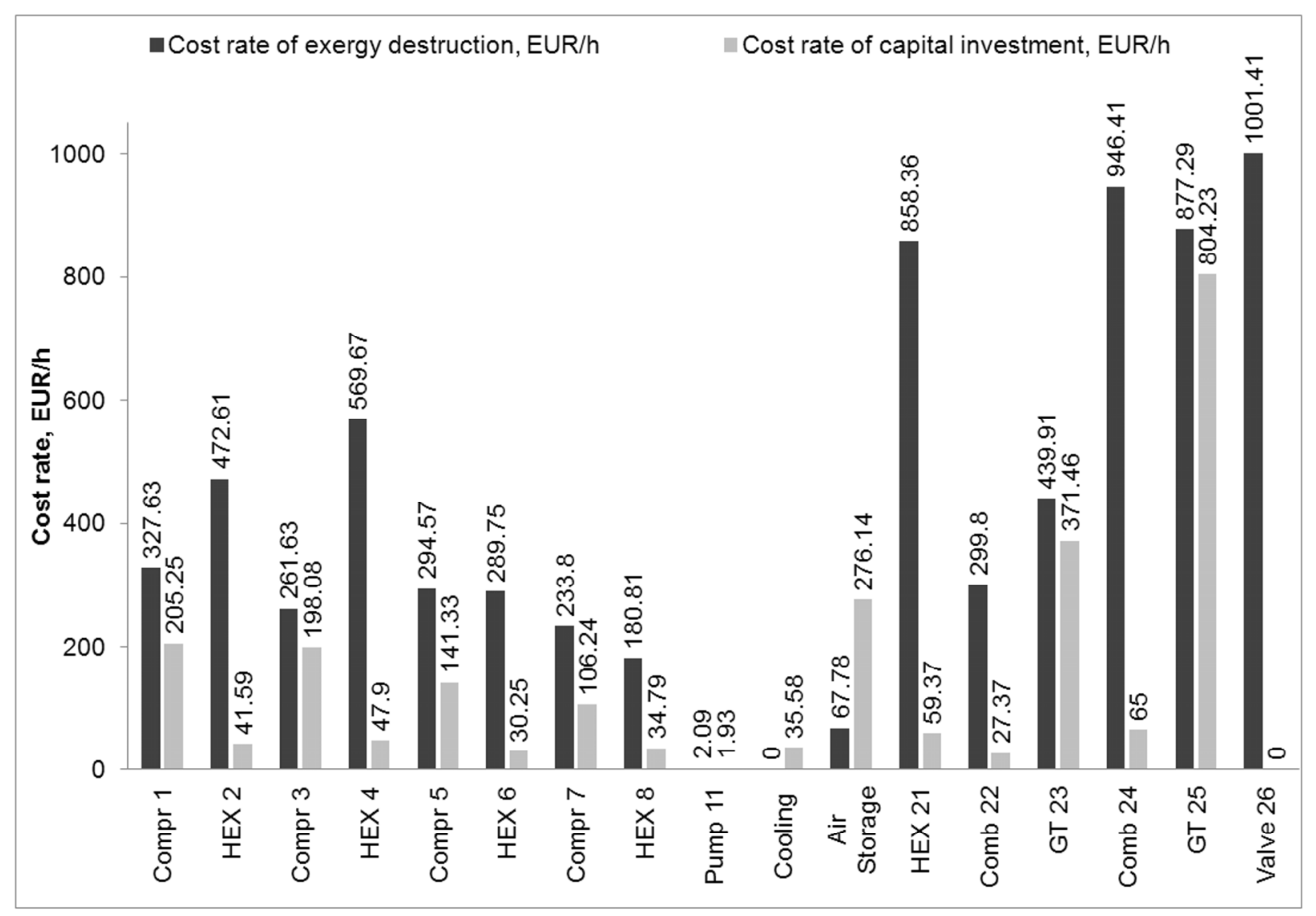

Fig. 6 . Exergoeconomic analysis of CAES system 


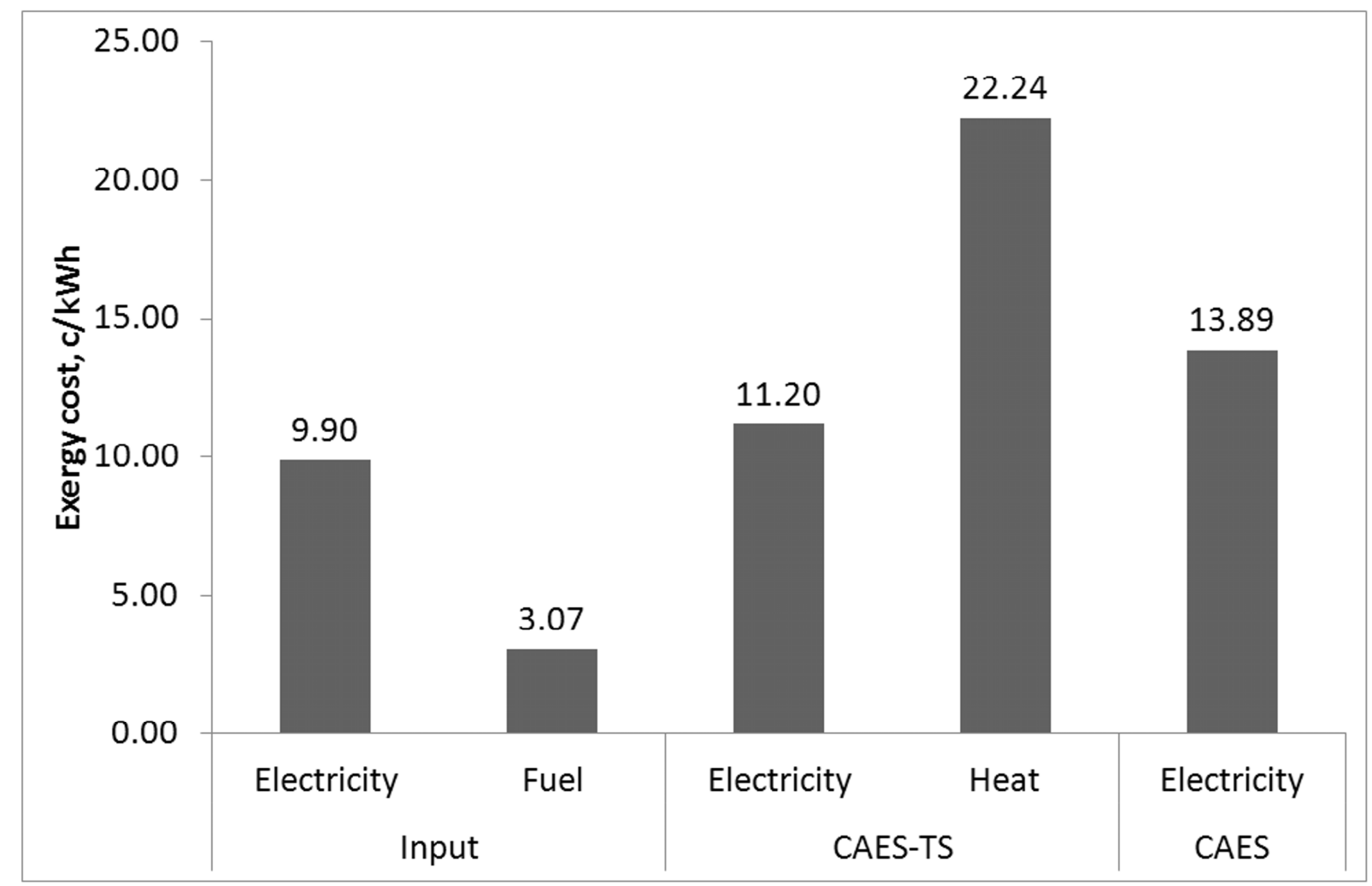

Fig. 7. Exergy costs of products 

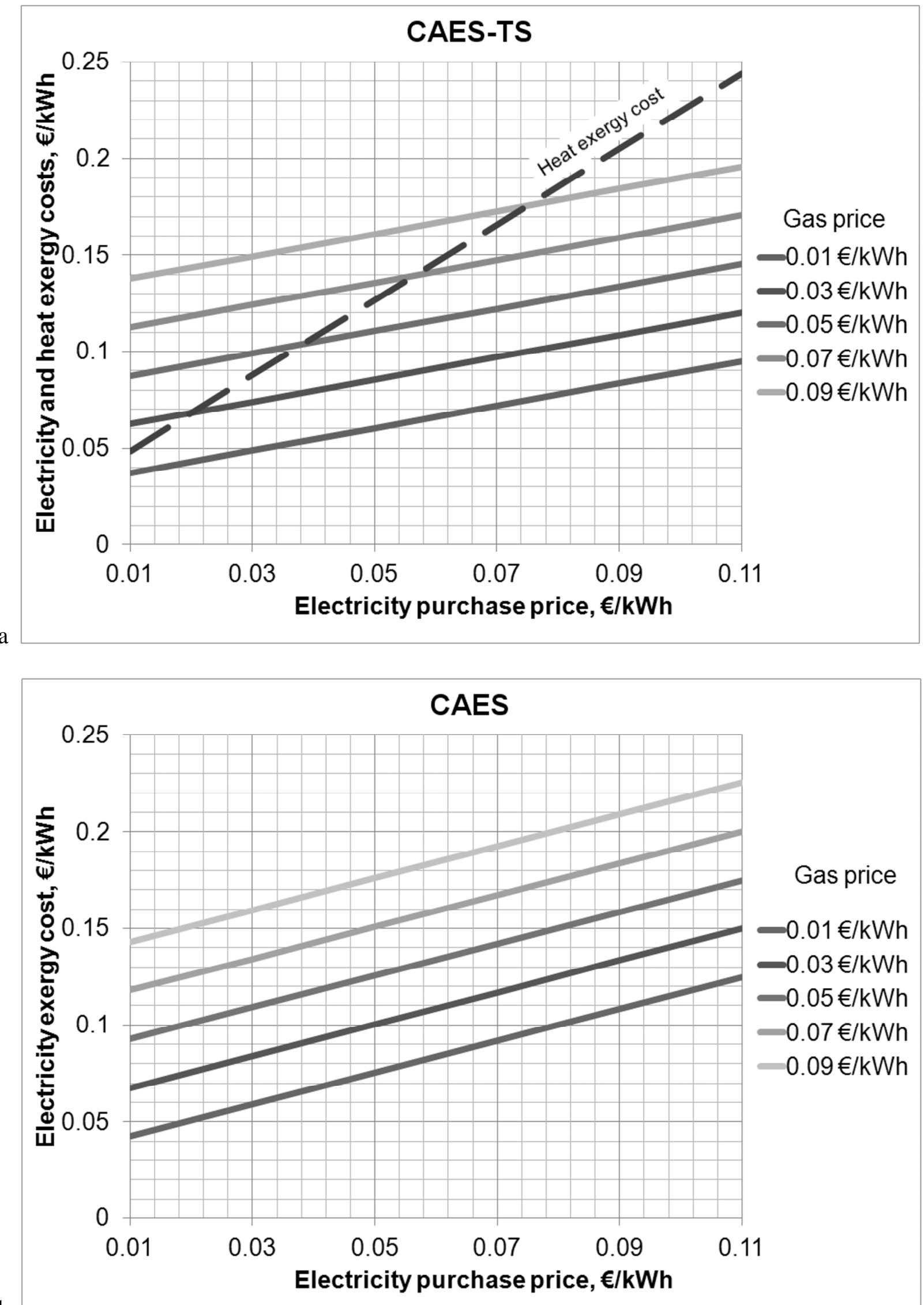

Fig. 8. Variation of exergy costs of products depending on fuel prices: (a) for CAES-TS and (b) for CAES systems 
Table 1. Simulation data of CAES-TS

Parameter

Value

\section{Compression stage}

Air mass flow rate $(\mathrm{kg} / \mathrm{s}) \quad 197$

Cooling water mass flow rate $(\mathrm{kg} / \mathrm{s}) \quad 502$

Air temperature $\left({ }^{\circ} \mathrm{C}\right)$ :

after $1^{\text {st }}$ compression stage $\quad 188$

$\begin{array}{ll}\text { after } 2^{\text {nd }} \text { compression stage } & 217\end{array}$

$\begin{array}{ll}\text { after } 3^{\text {rd }} \text { compression stage } & 170\end{array}$

$\begin{array}{ll}\text { after } 4^{\text {th }} \text { compression stage } & 140\end{array}$

$\begin{array}{ll}\text { after all heat exchangers } & 50\end{array}$

Cooling water temperature $\left({ }^{\circ} \mathrm{C}\right)$ :

$\begin{array}{ll}\text { Supply } & 40\end{array}$

$\begin{array}{ll}\text { Return } & 90\end{array}$

Electrical input (MW):

$\begin{array}{ll}\text { compressor (1) } & 35.3\end{array}$

$\begin{array}{ll}\text { compressor (3) } & 34.1\end{array}$

$\begin{array}{ll}\text { compressor (5) } & 24.3\end{array}$

compressor (7) 18.3

$\begin{array}{ll}\text { Total (including pump) } & 112.1\end{array}$

$\begin{array}{lc}\text { Total heat output (MWth) } & 105.3\end{array}$

$\begin{array}{ll}\text { Operating time (h/year) } & 2747\end{array}$

Expansion stage

$\begin{array}{ll}\text { Air mass flow rate }(\mathrm{kg} / \mathrm{s}) & 147\end{array}$ 
Turbine operating pressure (after throttling) (bar)

Fuel energy input (MW) (HHV based)

Fuel consumption rate $(\mathrm{kg} / \mathrm{s})$

Electricity output (MW)

Operating time (h/year)

\section{Storage}

Air storage cavern volume $\left(\mathrm{m}^{3}\right)$

Max pressure in cavern (bar)

Min pressure in cavern (bar)

Wall temperature in the cavern $\left({ }^{\circ} \mathrm{C}\right)$

Water storage volume $\left(\mathrm{m}^{3}\right)$ 
Table 2.Energy and exergy efficiency of the CAES-TS

\begin{tabular}{lcc}
\hline Parameter & Energy & Exergy \\
\hline Electricity input, $W_{c}$ or $E_{c}(\mathrm{GWh} /$ year $)$ & 307.94 & 307.94 \\
Fuel input, $F$ or $E_{f}(\mathrm{GWh} /$ year $)$ & 465.95 & 440.27 \\
Heat output, $Q$ or $E_{q}(\mathrm{GWh} /$ year $)$ & 289.26 & 42.41 \\
Electricity output, $W_{\text {tur }}$ or $E_{\text {tur }}(\mathrm{GWh} /$ year $)$ & 374.81 & 374.81 \\
Electric efficiency, \% & $\mathbf{4 8 . 4}$ & $\mathbf{5 0 . 1}$ \\
Total efficiency, \% & $\mathbf{8 5 . 8}$ & $\mathbf{5 5 . 8}$
\end{tabular}

Note: Based on Higher Heating Value, including auxiliary power consumption 